\title{
Upaya Meningkatkan Hasil Belajar Matematika Melalui Model Cooperative Learning Di Kelas 1 SDLB Seunagan
}

\author{
Nurhasanah \\ Guru SDLB Seunagan
}

\begin{abstract}
Abstrak
Penelitian ini bertujuan untuk mengetahui keberhasilan peningkatan hasil belajar siswa kelas V SDLB Negeri Seunagan dalam pembelajaran matematika tentang penjumlahan dan pengurangan pecahan. Metode penelitian yang digunakan adalah model pembelajaran matematika kooperatif tipe STAD dengan pelaksanaannya 2 siklus, dimana setiap siklus melalui 4 tahapan yaitu perencanaan, tindakan, observasi, dan refleksi. Subyek penelitian adalah siswa/siswi kelas 1 SDLB Negeri Seunagan yang berjumlah 32 orang. Pengumpulan data didapatkan dari lembar observasi guru, lembar observasi siswa, LKS dan tes individu. Hasil penelitian didapatkan bahwa rata-rata hasil uji kompetensi belajar siswa meningkat mulai dari tahap pra penelitian sampai ke siklus II. Pada tahap pra penelian, dari seluruh jumlah siswa 32 siswa baru mampu melewati nilai minimal/standar kelulusan (65\%) yang telah ditentukan yaitu 7.0. Pada siklus I yang mampu melewati nilai standar kelulusan baru mencapai orang $(69,375 \%)$ sedangkan yang belum mencapai standar kelulusan sebanyak 15 orang $(46,875 \%)$. Pada siklus II didapatkan 32 orang siswa sudah mencapai standar kelulusan (100\%) dari seluruh jumlah siswa 32 orang. Siswa sudah mampu melewati nilai minimal/standar kelulusan KKM secara keseluruhan, Peneliti menyimpulkan bahwa proses pembelajaran dengan menerapkan model pembelajaran matematika kooperatif tipe STAD dapat meningkatkan prestasi belajar siswa, antusias siswa terhadap pelajaran matematika kooperatif tipe STAD dan aktifitas belajar mengajar dalam bidang studi matematika meningkat.
\end{abstract}

\section{Kata Kunci : Hasil Belajar, Matematika, Model Cooperative Learning}

\section{PENDAHULUAN}

Matematika adalah salah satu dasar penguasaan ilmu dan teknologi, baik aspek terapannya maupun aspek penalarannya. Salah satu ciri utama matematika adalah penggunaan simbol-simbol. Untuk menyatakan sesuatu misalnya menyatakan suatu fakta, konsep operasi ataupun prinsip/aturan. Ada dua hal yang mendukung arah penguasaan matematika untuk anak didik sekarang ini, yaitu: (1) Matematika diperlukan sebagai alat bantu untuk memahami terjadinya peristiwa-peristiwa alam dan sosial, (2) Matematika telah memiliki semua kegiatan manusia, baik untuk keperluan sehari-hari maupun keperluan profesional ( Abdullah,2008).

Jenning dan Dunne (abdullah,2008) mengatakan bahwa, pada umumnya siswa mengalami kesulitan dalam mengaplikasikan matematika ke dalam situasi kehidupan real. Hal lain yang menyebabkan sulitnya matematika bagi siswa adalah karena pembelajaran matematika kurang bermakna. Berbagai model pembelajaran yang dilaksanakan oleh guru pada umumnya untuk membantu siswa agar mampu memahami dan mengerti apa yang dipelajarinya. Sebagai upaya meningkatkan hasil belajar siswa, salah satu model pembelajaran yang menjadi alternatif adalah dengan menggunakan atau menerapkan model pembelajaran kooperatif tipe STAD.

Dari hasil yang di dapatkan pada tahun pelajaran 2018/2019 bahwa nilai matematika peserta didik kelas V SDLB Negeri Seunagan masih dibawah KKM yang 
telah ditentukan, ini dapat dilihat dari nilai rata-rata kelas tes awal antara lain baru mencapai 65 ,sedangkan KKM yang ditentukan adalah 70 . Karena metode dan teknik yang digunakan masih kurang tepat, dimana guru kelihatan yang lebih aktif menyampaikan informasi, namun murid masih saja pasif dalam menerima pelajaran . Kesempatan bagi murid untuk melakukan refleksi tidak ada, interaksi antara murid dengan murid, dan murid dengan guru kurang dikembangkan. Dengan pembelajaran tersebut murid tidak mendapat kesempatan untuk mengembangkan ide-ide kreatif dan menemukan berbagai alternatif pemecahan masalah, tetapi mereka menjadi sangat tergantung pada guru, tidak terbiasa melihat alternatif lain yang mungkin dapat dipakai menyelesaikan masalah secara efektif dan efisien. Diduga salah satu faktor yang menyebabkan kondisi tersebut adalah kurang tepatnya model pembelajaran yang digunakan oleh guru.dan siswa kurang menguasai konsep dasar perkalian dan pembagian

\section{Tujuan Penelitian}

Penelitian ini bertujuan untuk mengetahui keberhasilan peningkatan hasil belajar siswa kelas V SDLB Negeri Seunagan dalam pembelajaran matematika tentang penjumlahan dan pengurangan pecahan.

\section{KAJIAN PUSTAKA}

\section{Hakikat Matematika Di Sekolah Dasar}

Pembelajaran adalah proses interaksi peserta didik dengan pendidik dan sumber belajar pada suatu lingkungan belajar. Pembelajaran merupakan juga pemberian bantuan yang diberikan pendidik kepada peserta didik agar dapat terjadi proses pemerolehan ilmu dan pengetahuan, penguasaan kemahiran dan tabiat, serta pembentukan sikap dan kepercayaan pada anak didik. Dengan kata lain, pembelajaran adalah proses untuk membantu peserta didik agar dapat belajar dengan baik.

Tujuan dari pelajaran matematika di Sekolah Dasar (Depdiknas:2003) adalah agar peserta didik memiliki kemampuan sebagai berikut:

1. Memahami konsep matematika, menjelaskan keterkaitan antar konsep dan mengaplikasikan konsep atau algoritma secara luwes, akurat, efisien, dan tepat dalam pemecahan masalah.

2. Menggunakan penalaran pada pola dan sifat, melakukan manipulasi matematika dalam membuat generalisasi, menyusun bukti, atau menjelaskan gagasan dan pertanyaan matematika.

3. Memecahkan masalah yang meliputi kemampuan memahami masalah, merancang model matematika, menyelesaikan model dan menafsirkan solusi yang diperoleh.

4. Mengomunikasikan gagasan dengan simbol, tabel, diagram, atau media lain untuk memperjelas keadaan atau masalah.

5. Memiliki sikap menghargai kegunaan matematika dalam kehidupan, yaitu memiliki rasa ingin tahu, perhatian, dan minat dalam mempelajari matematika, serta sikap ulet dan percaya diri dalam pemecahan masalah

\section{Pengertian Belajar}

Dalam proses pengajaran, unsur proses memegang peranan penting. Mengajar adalah proses membimbing kegiatan belajar dan kegiatan belajar hanya bermakna jika terjadi kegiatan belajar siswa. Oleh karena itu, penting sekali memahami sebaikbaiknya tentang proses belajar siswa, agar guru dapat memberikan bimbingan dan menyediakan lingkungan belajar yang tepat dan serasi bagi siswa. 
Menurut Mustaqin (2004:6) Belajar adalah "proses perubahan tingkah laku yang relatif tetap yang diakibatkan oleh pengalaman dan latihan". Perubahan yang dimaksud dalam belajar bukan saja semua perubahan yang terjadi dalam tubuh manusia, seperti perubahan karena kelelahan, perubahan karena pertambahan usia, perubahan karena menggunakan obat-obatan dan sebagainya juga perubahan yang terjadi dalam kehidupan sehari-hari manusia itu sendiri.

\section{Pengertian Pembelajaran}

Menurut Degeng (dalam ratumanan 2002:3), "Pembelajaran merupakan upaya untuk membelajarkan seseorang. Artinya, pembelajaran merupakan segala perilaku seseorang yang bertujuan untuk mengubah perilaku orang lain. Berdasarkan definisi tersebut, maka yang dimaksud dengan pembelajaran adalah usaha untuk mengubah struktur, kognitif, afektif dan psikomotorik siswa melalui penataan belajar.

Gagne dan Briggs mengartikan pembelajaran adalah "suatu sistem yang bertujuan untuk membantu proses belajar siswa yang berisi serangkaian peristiwa yang dirancang, disusun sedemikian rupa untuk mempengaruhi dan mendukung terjadinya proses belajar siswa yang bersifat internal".

\section{Unsur Dasar Pembelajaran Kooperatif}

Pembelajaran kooperatif adalah suatu sistem yang di dalamnya terdapat elemenelemen yang saling terkait. Adapun berbagai elemen dalam pembelajaran kooperatif adalah adanya: "(1) saling ketergantungan positif; (2) interaksi tatap muka; (3) akuntabilitas individual, dan (4) keterampilan untuk menjalin hubungan antar pribadi atau keterampilan sosial yang secara sengaja diajarkan" (Abdurrahman \& Bintoro, 2000:78-79).

\section{Pembelajaran Cooperative Tipe STAD}

Pembelajaran kooperatif Tipe STAD (Student Teams Achievement Division) adalah suatu model pembelajaran yang menekankan adanya kerjasama antara siswa. Siswa dibagi kedalam beberapa kelompok secara heterogen. Berikut ini model pembelajaran yang dapat mewakili model-model cooperative learning :

1. Student teams achievement division (STAD), langkah-langkah:

a. Membentuk kelompok yang anggotanya 4 orang.

b. Guru menyajikan materi pelajaran.

c. Guru memberi tugas untuk dikerjakan, anggota kelompok yang mengetahui jawabannya memberikan penjelasan kepada anggota kelompok.

d. Guru memberikan pertanyaan/kuis dan siswa menjawab pertanyaan/kuis dengan tidak saling membantu.

e. Guru memberikan kesimpulan

\section{METODE}

\section{Jenis Penelitian}

Penelitian ini adalah penelitian tindakan kelas (Classroom Action Researh). Tindakan yang diberikan adalah proses pembelajaran dengan menerapkan model pembelajaran kooperatif tipe STAD yang dibagi dalam dua siklus dengan empat tahapan, yaitu (a) perencanaan tindakan, (b) pelaksanaan tindakan, (c) observasi dan evaluasi dan (d) refleksi. 


\section{Tempat dan Waktu Penelitian}

Penelitian ini berlokasi di SDLB Seunagan dengan subjek penelitian adalah Siswa kelas 1 dengan jumlah siswa 32 orang yang terdiri dari : laki-laki 21 orang dan perempuan 11 orang pada semester ganjil tahun pelajaran 2018/2019. Waktu Penelitian akan dilaksanakan bertepatan dengan materi sajian tentang Penjumlahan dan pengurangan pecahan semester ke I ,tepatnya pada bulan bulan Juli 2018.

\section{Subjek Penelitian}

Subjek dalam penelitian ini adalah siswa-siswi kelas 1 SDLB Negeri Seunagan. Dengan jumlah total sebanyak 32 siswa, yang terdiri dari 21 orang siswa dan 11 orang siswi.

\section{HASIL PENELITIAN DAN PEMBAHASAN}

Adapun yang dianalisis adalah deskriptif mengenai perubahan hasil belajar siswa setelah dilakukan pembelajaran dengan menggunakan model pembelajaran kooperatif tipe STAD pada siklus I dan siklus II berdasarkan hasil tes pada tiap akhir siklus. Disamping itu akan dianalisis pula refleksi terhadap pelaksanaan tindakan dalam proses belajar mengajar matematika dengan menggunakan model pembelajaran kooperatif tipe STAD. Pada tahap ini pula penulis menganalisis perubahan sikap siswa berdasarkan hasil pengamatan dan observasi maupun refleksi.

\section{Deskripsi Hasil Pra Penelitian}

Gambaran kondisi awal sebelum mengadakan penelitian tindakan kelas pembelajaran matematika seperti biasanya dilakukan antara lain menjelaskan cara menjumlah pecahan,dan mengurang pecahan biasa lalu di observasi sebagai input data pembanding dengan hasil penelitian nantinya maka observasi dan data yang diambil adalah menitik beratkan pada hasil belajar siswa sebelum dan sesudah kegiatan pembelajaran menerapkan pembelajaran model kooperatif tipe STAD untuk melihat seberapa besar ketuntasan belajar siswa dengan menerapkan model pembelajaran tersebut.

Data awal yang dapat dilihat pada kegiatan prasiklus antara lain siswa kurang tertarik dengan materi sajian dan guru bingung untuk mengajar materi pecahan sehingga hasil yang diharapkan kurang memuaskan, masih banyak siswa yang belum mencapai KKM yang ditetapkan.

Aktivitas siswa dalam belajar mata pelajaran matematika masih menunjukkan beberapa aspek yang masih kurang, diantaranya rasa ingin tahu siswa terhadap hal-hal yang sedang dipelajari, partisipasi siswa dalam kegiatan belajar mengajar, kreativitas siswa dalam belajar, kerjasama dan percaya diri yang kurang terbangun.

Dengan hal-hal seperti ini, hasil belajar siswa yang didapatkan dalam tahap pra penelitian juga terlihat rata-rata hasil belajar siswa masih kurang, hal itu dapat kita lihat dari tabel perolehan skor siswa pada tahap pra penelitian berikut ini.

Analisis kuantitatif

\section{Analisis Deskriptif Hasil Belajar Siswa Pada Tes Awal Siklus}

Tes awal yang dilakukan peneliti bertujuan untuk memperoleh gambaran awal tentang hasil belajar siswa dalam proses belajar mengajar. Tes awal ini akan dijadikan acuan untuk melihat sejauh mana keberhasilan metode pengajaran dengan model pembelajaran kooperatif tipe STAD. Adapun hasil analisis statistik deskriptif pada skor hasil belajar siswa kelas 1 SDLB Negeri Seunagan sebelum dilakukan pembelajaran dengan menggunakan model pembelajaran kooperatif tipe STAD dapat dilihat pada tabel dibawah ini. 
Tabel Distribusi Frekuensi dan Persentase Skor Hasil Belajar Siswa Kelas 1 SDLB Negeri Seunagan Sebelum dilakukan Pembelajaran model kooperatif tipe STAD

\begin{tabular}{|c|c|c|c|}
\hline Skor & Kategori & Frekuensi & Persentase (\%) \\
\hline$<70$ & Tidak tercapai & 23 & 71,875 \\
\hline$=70$ & Tercapai & 5 & 15,625 \\
\hline$>70$ & Melampaui & 8 & 25 \\
\hline \multicolumn{2}{|c|}{ Jumlah } & 32 & 100,0 \\
\hline
\end{tabular}

Pada tabel terlihat bahwa hasil belajar siswa dalam pembelajaran matematika sebelum dilakukan pembelajaran dengan menggunakan model pembelajaran kooperatif tipe STAD, menunjukkan bahwa dari 23 siswa memperoleh nilai dibawah KKM,sedangkan sama dengan KKM yang ditetapkan berjumlah 5 orang siswa atau $15,625 \%$ sedangkan frekuensinya diatas KKM baru mencapai 8 orang siswa atau baru mencapai $25 \%$. Untuk lebih jelasnya dapat dilihat pada tabel 4.1

\section{Deskripsi Penelitian Siklus I}

\section{a. Rencana Tindakan}

Sebelum pelaksanaan kegiatan penelitian tindakan kelas dilakukan penelitian terlebih dahulu dilakukan persiapan, antara lain

a. Menyusun Rencana Pelaksanaan Pembelajaran I (RPP I).

b. Menyiapkan alat pembel;ajaran tentang pecahan .

c. Menyiapkan lembar kerja siswa (LKS).

d. Membuat lembar observasi (pengamatan) aktifitas guru dan siswa dalam proses belajar mengajar dengan menggunakan model belajar cooperative tipe STAD

Menentukan alokasi waktu,menyiapkan alat dan bahan yang diperlukan,siswa yang akan menjadi objek penelitian, orang yang ditunjuk untuk menjadi observer, media penyimpan data siklus, baik berbentuk foto maupun dalam bentuk lainnya. Materi yang diangkat adalah pokok bahasan tentang penjumlahan dan pengurangan pecahan.

\section{b. Pelaksanaan Tindakan}

Secara terperinci langkah-langkah kegiatan pembelajaran selama siklus I dapat dilihat pada RPP terlampir, namun secara garis besar pelaksanaan siklus I dapat digambarkan sebagai berikut:

Pada awal kegiatan, guru mengadakan Tanya jawab tentang pembelajaran yang akan berlangsung dilanjutkan dengan menyampaikan tujuan pembelajaran yang akan berlangsung dan mengkondisikan siswa untuk belajar matematika materi penjumlahan dan pengurangan pecahan guru mengajukan guru mengajukan pertanyaan bagaimana penjumlahan dan pengurangan pecahan $1 / 2+2 / 4$. Siswa diminta Melakukan percobaan dengan menggunakan kertas berlipat untuk dapat membantu siswa memahami definisi pecahan yang dapat diambil dari kehidupan sehari-hari.

\begin{tabular}{l|l}
$1 / 2$ & $1 / 2$
\end{tabular}

\begin{tabular}{|l|l|l|l|}
\hline $1 / 4$ & $1 / 4$ & $1 / 4$ & $1 / 4$ \\
\hline
\end{tabular}

Kertas yang dibagi dua juga harus dibagi 4

Nama lain dari $1 / 2$ adalah $2 / 4$ berarti $\rightarrow^{1 / 2}=2 / 4$

Jadi $2 / 4+2 / 4=4 / 8$

Cara yang ke 2

$1 / 2+2 / 4=K P K$ dari 2 dan 4 adalah 8 ,

$2,4,6,8,10,12,14,16,18,20$ 


\section{Cara ke 3}

$\mathrm{N}$ i la i senama dari $1 / 2$ da $2 / 4$ adalah

$1 / 2,2 / 4,4 / 8,8 / 16$

$2 / 4,4 / 8,8 / 16$

Jadi $2 / 4$ dtabah $2 / 4=4 / 8$

Guru mengelompokkan siswa mejadi 6 kelompok yang masing-maing kelompok terdiri dari $5-6$ orang siswa .Guru mulai membagikan LKS pembelajaran I serta alat yang diperlukan. Mulailah siswa bekerja dalam kelompoknya dengan panduan LKS dari guru untuk menemukan dan membuktikan kebenaran konsep dan fakta-fakta tentang pecahan.

\begin{tabular}{|l|l|l|l|l|l|}
\hline \multicolumn{2}{|c|}{$1 / 3$} & \multicolumn{2}{c|}{$1 / 3$} \\
\hline $1 / 6$ & $1 / 6$ & $1 / 6$ & $1 / 6$ & $1 / 6$ & $1 / 6$ \\
\hline
\end{tabular}

1. Amati panjang dua buah pita pada gambar di atas , $1 / 3$ panjang pita sama dengan $2 / 6$ panjang pita ( $b$ ) dengan kata lain $1 / 3$ panjang pita a sama dengan $2 / 6$ panjang pita ( b ) .

2. Nama Lain dari $1 / 3$ adalah $2 / 6,3 / 9,4 / 12,5 / 15$

3. Tentukan penjumlahan pecahan dengan menggunakan nilai pecahan senama

- $2 / 5+3 / 4$

- $2 / 4+3 / 6$

$-23+3 / 5$

Selama siswa bekerja guru lebih berperan sebagai fasilitator dan pembimbing siswa dan bukan satu-satunya narasumber bagi siswa. Di penghujung pembelajaran siswa langsung didiskusikan bersama semua teman-temannya untuk mendapatkan kesimpulan akhir, dan pada saat itulah guru memberikan penguatan konsep tentang Selama kegiatan pembelajaran siswa terlihat aktif dan lebih inten dalam berinteraksi dengan teman-temannya, peran guru terlihat tidak memonopoli kegiatan belajar mengajar, keberanian siswa pun mulai terbangun dan merata. Namun walaupun demikian, hasil belajar siswa terlihat memberikan gambaran kemajuan yang cukup signifikan dan mengalami peningkatan.

\section{Tahap Observasi /evaluasi}

\section{Tingkat aktivitas guru dalam mengelola pembelajaran}

Hasil pengamatan yang dilakukan oleh teman sejawat tingkat aktivitas guru dalam mengelola pembelajaran dengan pemberian tugas kelompok dan tes formatif kepada siswa kelas 1 SDLB Negeri Seunagan pada siklus I adalah sebagai berikut.

Tabel Hasil Pengamatan kemampuan Guru Mengelola Pembelajaran Siklus I

No Aspek Penilaian

Skor

1. Kegiatan Awal

- Melakukan kegiatan apersepsi

- Menyampaikan langkah pembelajaran 3

2. Kegiatan Inti

- Menyampaikan tujuan pembelajaran

4

\section{Penggunaan Materi Pembelajaran}

- penguasaan materi pembelajaran

- Mengaitkan materi dengan pengetahuan lain yang relevan

- Menyampaikan materi dengan jelas, sesuai dengan tujuan Pembelajaran 
- Mengaitkan materi dengan realitas kehidupan

Pendekatan/ Strategi Pembelajaran

- Melaksanakan pembelajaran sesuai dengan kompetensi 2 (tujuan) yang akan dicapai dan karakteristik siswa

- Menguasai kelas

- Melaksanakan pembelajaran yang bersifat kontekstual 3

- Melaksanakan pembelajaran yang memungkinkan 3 tumbuhnya kebiasaan positif

- Melaksanakan pembelajaran sesuai alokasi waktu yang 2 direncanakan

Pembelajaran yang memicu dan memelihara keterlibatan siswa

- Menumbuhkan partisipasi aktif siswa dalam pembelajaran 3

- Menunjukkan sikap terbuka terhadap respons siswa 3

- Menumbuhkan keceriaan dan antusiasme siswa 2

Penilaian Proses dan Hasil Belajar

- Memantau kemajuan belajar selama proses 3

- Melakukan penilaian akhir sesuai dengan kompetensi 2

Penggunaan Bahasa

- Menggunakan bahasan lisan dan tulisan secara jelas, baik

3
dan benar

\section{Penutup}

- Melakukan refleksi atau membuat rangkuman dengan 2 melibatkan siswa

- Melaksanakan tindak lanjut dengan memberikan arahan atau 2 kegiatan atau tugas sebagai bagian pengayaan

Jumlah Skor

Rata-rata

Sumber: Data Primer (diolah)

Berdasarkan analisis data tingkat aktivitas guru dalam mengelola pembelajaran pada siklus I, dapat dilihat pada Tabel Skor rata-rata setiap aspek yang diamati dalam mengelola pembelajaran termasuk kategori cukup. Hal ini menunjukkan bahwa kemampuan guru dalam mengelola pembelajaran dengan menggunakan model cooperative learning tipe STAD dalam pembelajaran matematika masih harus ditingkatkan lagi karena masih dalam kategori cukup.

Hasil kegiatan pada siklus I ini memperlihatkan adanya peningkatan hasil belajar siswa, dengan membandingkan perolehan hasil belajar siswa pada saat tahap pra penelitian dengan saat tes diakhir siklus I yang terlihat adanya peningkatan perolehan nilai. Secara persentase dapat dilihat besarnya persentase nilai siswa pada tahap silkus I pada:

Tabel Distribusi Frekuensi dan Persentase Skor Hasil Belajar Siswa Kelas 1 SDLB Negeri Seunagan Sesudah dilakukan Pembelajaran model kooperatif tipe STAD (siklus pertama)

\begin{tabular}{|c|c|c|c|}
\hline Skor & Kategori & Frekuensi & Persentase (\%) \\
\hline$<70$ & Tidak tercapai & 15 & 46,875 \\
\hline$=70$ & Tercapai & 7 & 21,875 \\
\hline$>70$ & Melampaui & 10 & 31,25 \\
\hline \multicolumn{2}{|c|}{ Jumlah } & 32 & 100,0 \\
\hline
\end{tabular}


Pada tabel diatas terlihat bahwa hasil belajar siswa dalam pembelajaran matematika sesudah dilakukan tindakan dengan menggunakan model pembelajaran kooperatif tipe STAD, menunjukkan bahwa dari 15 siswa memperoleh nilai dibawah KKM,dengan kata lain sudah berkurang dari 23 siswa yang belum mencapai KKM berkurang menjadi 15 orang sedangkan sama dengan KKM yang ditetapkan berjumlah 7 orang siswa atau 21,875 \% sedangkan frekuensinya diatas KKM sudah mencapai 10 orang siswa atau bertambah 2 orang dari $25 \%$ sudah bertambah menjadi $31,25 \%$ atau sudah bertambah 2 orang siswa.

\section{Refleksi Hasil Belajar Siswa Pada Tes Siklus I}

Hasil analisis statistik deskriptif pada skor hasil belajar siswa kelas 1 SDLB Negeri Seunagan setelah dilakukan pembelajaran dengan menggunakan model pembelajaran kooperatif tipe STAD sudah mengalami peningkatan pada jumlah siswa yang mencapai KKM,yaitu dari 13 orang siswa, menjadi 17 siswa (dari 40,625\% menjadi 53,125\%) Berdasarkan refleksi hasil pembelajaran siklus pertama ,masih banyak siswa yang belum mencapai KKM maka guru mempersiapkan perencanaan untuk siklus ke 2 dengan memperbaiki pada srategi pembelajaran ,penambahan alat pembelajaran untuk mendukung hasil belajar siswa.

\section{Deskripsi Penelitian Siklus II \\ a. Rencana Tindakan}

Setelah memperhatikan hasil belajar, hasil pengamatan dan hasil diskusi dengan pihak observer, serta ditemukannya beberapa kekurangan yang harus diperbaiki, maka peneliti dan observer sepakat untuk melakukan kegiatan penelitian kembali di siklus II sebagai tindak lanjut dari hasil pada siklus I, kemudian dilakukan persiapan kembali mulai dari Rencana persiapan pembelajaran ,alat dan bahan yang digunakan untuk menjelaskan materi pecahan yaitu berupa tayangan gambar pembelajaran matematikamelalui vidio pembelajaran, instrument pengumpulan data, siswa yang akan menjadi objek penelitian, orang yang ditunjuk untuk menjadi observer, media penyimpan data siklus, baik berbentuk foto maupun dalam bentuk lainnya. Materi yang diangkat adalah pokok bahasan tentang pengurangan pecahan.

\section{b. Pelaksanaan Tindakan}

Sebelum memulai pembelajaran terlebih dahulu guru mengajak siswa berdoa, dilanjutkan dengan kegiatan literasi selama 10 menit dan mengkondisikan siswa untuk menerima materi sajian dengan mengadakan tanya jawab tentang pembelajaran yang lalu dan dikaitkan dengan pembejajaran yang akan berlangsung, Secara terperinci langkah-langkah kegiatan pembelajaran selama siklus II dapat dilihat pada RPP (terlampir), mengkondisikan siswa dari suasana diluar kelas ke suasana pembelajaran, setelah siswa dalam kondisi siap belajar, guru mengajukan beberapa masalah kepada siswa kali ini dengan memberi penguatan dan pengkondisian kelas dengan memberikan reinforment dan menumbuhkan rasa kepercayaan diri siswa yang memberikan kesan rileks pada siswa namun tetap dalam kondisi belajar agar siswa tidak terlalu tegang ketika berinteraksi dengan guru, dilanjutkan dengan menyampaikan tujuan pembelajaran yang akan berlangsung dan mengkondisikan siswa untuk belajar matematika materi pengurangan pecahan, guru menunjukkan pecahan : $\mathbf{3} / \mathbf{4}-\mathbf{1} / \mathbf{2}$

Guru menayangkan vidio tentang pengurangan pecahan, Boleh dicari dengan KPK dan boleh dicari dengan nilai yang sama pada pecahan $1 / 2$.

Cara 1

KPK dar 4 dan 2 adalah :

$$
\text { i. } 2,4,6,8,10,12,14,16
$$


ii. $4,8,12,16,20,24,28$

iii. KPK adalah 4 atau penyebut adalah 4

$3 / 4-1 / 2=3 / 4-2 / 4=1 / 4$

Cara 2
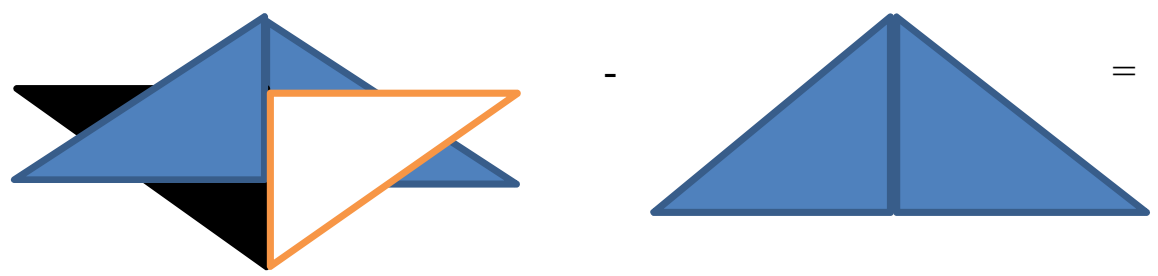

$3 / 4-1 / 2=3 / 4-2 / 4=1 / 4$

Cara ke $35 / 6-1 / 2=\mathrm{KPK}=5 / 6-3 / 6=2 / 6 \ldots \ldots \ldots .6: 6 \times 5=5 / 6-6: 2 \times 1=3 / 6$

$1 \times 2=2 \quad 1 \times 6=6$

$2 \times 2=4$

$3 \times 2=6 \quad 2 \times 6=12$

Setelah siswa megamati tayangan vidio tentang pengurangan pecahan dilanjutkan dengan pemberian tugas kepada siswa secara berkelompok siswa bekerja sesuai dengan lembaran kerja yang disajikan guru. Guru mengelompokkan siswa menjadi 6 kelompok yang masing-masing kelompok terdiri dari 5 orang siswa serta diketuai oleh seorang ketua kelompok dan tempat duduknya diatur berdekatan, anggota dipilih sedemikian rupa sehingga dalam satu kelompok terdiri dari anak pandai, anak sedang dan anak lamban. Hal ini dimaksudkan agar proses pembelajaran terjadi proses tutor sebaya. Ketika kelompok sudah terjadi, maka guru mulai membagikan LKS pembelajaran II serta alat yang diperlukan. Mulailah siswa bekerja dalam kelompoknya dengan panduan LKS dari guru untuk menemukan dan membuktikan kebenaran konsep dan fakta-fakta tentang pecahani. Selama siswa semua bekerja, guru lebih berperan sebagai fasilitator dan pembimbing siswa dan bukan satu-satunya narasumber bagi siswa. Di penghujung pembelajaran siswa diberi kesempatan untuk menyampaikan hasil temuannya dan langsung didiskusikan bersama temannya untuk mendapatkan kesimpulan akhir, dan pada saat itulah guru memberikan penguatan konsep tentang pengurangan pecahan. Di penghujung KBM guru melakukan tes akhir untuk melihat persentase efek dari metode yang digunakan terhadap siswa.

\section{Tahap Observasi dan penilaian}

Tahap aktivitas guru dalam mengelola pembelajaran

Hasil pengamatan yang dilakukan oleh teman sejawat tingkat aktivitas guru dalam mengelola pembelajaran dengan pemberian tugas tes formatif siswa kelas 1 SDLB Negeri Seunagan dengan menggunakan model belajar cooperative tipe STAD pada siklus II adalah sebagai berikut:

\section{Tabel Hasil Pengamatan kemampuan Guru Mengelola Pembelajaran Siklus II}

No Aspek Penilaian Skor

1. Kegiatan Awal

- Melakukan kegiatan apersepsi

- Menyampaikan tujuan pembelajaran

- Menyampaikan tujuan pembelajaran

2. Kegiatan Inti

Penggunaan Materi Pembelajaran

- penguasaan materi pembelajaran

- Mengaitkan materi dengan pengetahuan lain yang relevan 
- Menyampaikan materi dengan jelas, sesuai dengan tujuan Pembelajaran

- Mengaitkan materi dengan realitas kehidupan

Pendekatan/ Strategi Pembelajaran

- Melaksanakan pembelajaran sesuai dengan kompetensi 3 (tujuan) yang akan dicapai dan karakteristik siswa

- Menguasai kelas

- Melaksanakan pembelajaran yang bersifat kontekstual

- Melaksanakan pembelajaran yang memungkinkan tumbuhnya kebiasaan positif

- Melaksanakan pembelajaran sesuai alokasi waktu yang direncanakan

Pembelajaran yang memicu dan memelihara keterlibatan siswa

- Menumbuhkan partisipasi aktif siswa dalam pembelajaran

- Menunjukkan sikap terbuka terhadap respons siswa

- Menumbuhkan keceriaan dan antusiasme siswa

Penilaian Proses dan Hasil Belajar

- Memantau kemajuan belajar selama proses 4

- Melakukan penilaian akhir sesuai dengan kompetensi (tujuan) 4

Penggunaan Bahasa

- Menggunakan bahasan lisan dan tulisan secara jelas, baik dan benar

3. Penutup

- Melakukan refleksi atau membuat rangkuman dengan 4 melibatkan siswa

- Melaksanakan tindak lanjut dengan memberikan arahan atau 4 kegiatan atau tugas sebagai bagian pengayaan

\section{Jumlah Skor}

Rata-rata

Sumber: Data Primer (diolah)

Berdasarkan analisis data tingkat aktivitas guru dalam mengelola pembelajaran pada siklus II, dapat dilihat pada Tabel 4.3 skor rata-rata setiap aspek yang diamati dalam mengelola pembelajaran termasuk kategori baik. Hal ini menunjukkan bahwa kemampuan guru dalam mengelola pembelajaran dengan menggunakan model belajar cooperative tipe STAD pada pembelajaran matematika sudah memadai karena dalam kategori baik.

Selama kegiatan belajar mengajar pada siklus II ini kegiatan siswa dan guru terlihat ada perubahan, siswa terlihat lebih tenang dan guru lebih mampu mengefektifkan waktu yang tersedia karena tidak terlalu banyak waktu yang tersita untuk menjelaskan cara pengisian dan cara kerja dengan LKS.

Hasil kegiatan pada siklus II ini memperlihatkan adanya peningkatan hasil belajar siswa yang lebih signifikan dengan membandingkan hasil perolehan siswa pada saat tahap siklus I. Persentase nilai siswa pada tahap silkus II 
Serambi Konstruktivis, Volume 3, No.1, Maret 2021

ISSN : $2656-5781$

Tabel Distribusi Frekuensi dan Persentase Skor Hasil Belajar Siswa Kelas V SDLB Negeri Seunagan sesudah dilakukan Pembelajaran model kooperatif tipe STAD (Siklus ke 2)

\begin{tabular}{|c|c|c|c|}
\hline Skor & Kategori & Frekuensi & Persentase (\%) \\
\hline$<70$ & Tidak tercapai & 0 & 0 \\
\hline$=70$ & Tercapai & 15 & 46,875 \\
\hline$>70$ & Melampaui & 17 & 53,125 \\
\hline \multicolumn{2}{|c|}{ Jumlah } & 32 & 100,0 \\
\hline
\end{tabular}

Pada tabel terlihat bahwa hasil belajar siswa dalam pembelajaran matematika sesudah dilakukan tindakan dengan menggunakan model pembelajaran kooperatif tipe STAD, menunjukkan bahwa dari 15 siswa memperoleh nilai sudah mencapai KKM yang ditetapkan yaitu 70 ,dengan kata lain 15 orang siswa $(46,875 \%)$ sudah mencapai KKM yang sebelumnya belum mencapai KKM sebanyak 15 orang pada siklus pertama sedangkan frekuensinya diatas KKM sudah mencapai 17 orang siswa atau bertambah 7 orang yang mencapai KKM, dari 31,25\% sudah bertambah menjadi 53,125\% atau sudah bertambah 7 orang siswa.

2. Analisis Deskriptif Hasil Belajar Siswa Pada Tes Siklus ke II

Tingkat Hasil Belajar Siswa pada Tes Siklus ke dua

Hasil analisis statistik deskriptif pada skor hasil belajar siswa kelas 1 SDLB Negeri Seunagan pada siklus ke 2 setelah dilakukan pembelajaran dengan menggunakan model pembelajaran kooperatif tipe STAD sudah mengalami peningkatan jumlah siswa yang mencapai KKM 15 orang siswa sedangkan yang memperoleh nilai diatas KKM sudah mencapai 17 siswa $(53,125 \%)$

\section{Refleksi siklus II}

Siklus II terdiri dari 2 (dua) kali pertemuan dengan materi penjumlahan pecahan biasa berpenyebut sama dan berpenyebut berbeda. Materi disajikan diawali dengan mengaitkan materi yang akan dipelajari dengan keadaan sekitar, kemudian menyampaikan indikator pencapaian hasil belajar agar siswa mengetahui apa yang ingin dicapai pada materi tersebut. Setelah itu penulis menjelaskan materi secara singkat dan mengaitkannya dengan contoh benda yang ada dalam kehidupan seharihari. Dan mengelompokkan siswa dan membagikan LKS untuk setiap kelompok. Kemudian setelah itu diberikan kuis dan dikerjakan secara individu, Kemudian evaluasi.

Pada pertemuan kedua dan berikutnya, Materi disajikan diawali dengan mengaitkan materi yang akan dipelajari dengan materi sebelumnya, kemudian menyampaikan indikator pencapaian hasil belajar agar siswa mengetahui apa yang ingin dicapai pada materi tersebut. Setelah itu penulis menjelaskan materi secara singkat dan mengaitkannya dengan contoh benda yang ada dalam kehidupan seharihari. Dan mengelompokkan siswa dan membagikan LKS untuk setiap kelompok. Kemudian setelah itu diberikan kuis dan dikerjakan secara individu, kemudian evaluasi, menyimpulkan materi, memberikan penguatan .

\section{Pembahasan Hasil penelitian}

Pada siklus I ini apa yang ingin dicapai oleh peneliti telah tercapai, misalnya meningkatnya rata-rata hasil belajar siswa terhadap matematika yang terlihat pada table, namun masih ada hal-hal yang perlu diperbaiki pada siklus berikutnya.

Adapun hal-hal yang perlu diperbaiki pada siklus I antara lain :

1. Pada siklus I siswa dikelompokkan menurut absen, pengelompokan siswa diubah tidak berdasarkan nomor urut di absen namun dalam satu kelompok ada siswa yang 
pandai, sedang dan siswa yang kurang ,sehungga siswa yang kuarang dapat belajar pada siswa yang pandai. Namun siswa tetap dibagi dalam 6 kelompok dan pada setiap kelompok terdapat siswa yang memiliki kemampuan tinggi dan rendah.

2. Pada siklus I beberapa siswa belum menguasai cara menyamakan penyebut dengan KPK dan pecahan senilai, guru lebih fokus pada penjumlahan pecahan dengan menggunakan KPK. Pada penjumlahan dan pengurangan pecahan dengan menggunakan KPK siswa lebih paham dengan mengamati hasil perkalian dua angka dengan menunjukkan tabel perkalian yang hasilnya sama.

Siklus II terdiri dari 2 (dua) kali pertemuan dengan materi pengurangan pecahan yang berpenyebut sama dan berpenyebut berbeda dengan mengaitkan materi yang akan dipelajari dengan materi sebelumnya. Pada siklus ini penulis menekankan hal-hal yang perlu diperbaiki seperti cara menyamakan penyebut dengan menggunakan KPK dan cara menyamakan penyebut dengan pecahan senilai, kemudian penulis menyampaikan indikator pencapaian hasil belajar agar siswa mengetahui apa yang ingin dicapai pada materi tersebut.

Pada pertemuan pertama peneliti menjelaskan materi disajikan diawali dengan mengaitkan materi yang akan dipelajari dengan materi sebelumnya, kemudian menyampaikan indikator pencapaian hasil belajar agar siswa mengetahui apa yang ingin dicapai pada materi tersebut. Setelah itu penulis menjelaskan materi secara singkat dan mengaitkannya dengan contoh benda yang ada dalam kehidupan seharihari. Dan mengelompokkan siswa dan membagikan LKS untuk setiap kelompok. Kemudian setelah itu diberikan kuis dan dikerjakan secara individu, kemudian evaluasi, menyimpulkan materi, memberikan penguatan .

Pada siklus II ini, pada umumnya siswa lebih bersemangat lagi dengan model pembelajaran dengan cara berkelompok sehingga siswa dapat saling berdiskusi dan bertukar pikiran dalam memahami materi dan memecahkan atau menyelesaikan soal matematika. Pada siklus II ini apa yang ingin dicapai oleh peneliti tercapai. Hal ini dapat dilihat dari meningkatnya rata-rata hasil belajar siswa.

Disamping terjadinya peningkatan hasil belajar siswa pada siklus I dan siklus II, tercatat pula sejumlah perubahan sikap yang terjadi pada siswa. Perubahan tersebut merupakan data kualitatif dan dicatat oleh peneliti dalam lembar observasi tiap siklus. Adapun perubahan-perubahan yang dimaksud adalah sebagai berikut :

a. Pada siklus I keaktifan siswa sudah terlihat begitu juga pada siklus II.

b. Pada siklus I siswa masih malu-malu dalam bertanya kepada guru tentang masalah yang terkait dengan apa yang disajikan guru sedangkan pada siklus II siswa sudah berani untuk bertanya guru tentang masalah yang terkait dengan apa yang disajikan guru.

c. Pada siklus I interaksi siswa dengan sumber belajar/media sudah baik sedangkan pada siklus II interaksi siswa dengan sumber belajar/media jauh lebih baik .

d. Pada siklus I semua siswa aktif melakukan kegiatan fisik dan mental (berpikir), begitu juga pada siklus II.

e. Pada siklus I ketuntasan belajar siswa meningkat, itu dapat dilihat dari nilai rata-rata siswa pada siklus I 69,375 menjadi 73,75 pada siklus II.

Peneliti menyadari bahwa untuk menumbuhkan minat siswa dalam belajar matematika perlu dirancang model pembelajaran yang sesuai dengan situasi keadaan siswa, yang terpenting juga adalah membelajarkan siswa antusias, keberanian mengungkapkan gagasan, ide dan pemikiran serta meningkatkan hasil belajar matematika. Adanya peningkatan hasil belajar matematika pada siklus II tersebut 
menunjukkan bahwa banyak kemajuan yang dicapai oleh siswa setelah dilaksanakan pembelajaran model kooperatif tipe STAD.

Uraian tersebut diatas menunjukkan bahwa pembelajaran dengan menggunakan model kooperatif tipe STAD dapat meningkatkann hasil belajar siswa.

\section{Tindak lanjut hasil penelitian}

Hasil tes dan hasil pengamatan teman sejawat akan menjadi acuan untuk mengadakan perbaikan pada pembelajaran selanjutnya.tindak lanjut yang akan dilakukan antara lain pada pengelompokan siswa yang semula pengelompokan berdasarkan nomor urut,namun akan ditindak lanjuti dengan pengelompokan berdasarkan kemampuan siswa yang pandai,sedang dan siswa yang rendah kemampuan .Guru mengupayakan juga pada alat pembelajaran antara lain mengupayakan dengan menggunakan LCD untuk mudah dipahami siswa,siswa yang masih belum mencapai KKM akan diremedialkan diluar jam pembelajaran untuk membimbing siswa yang belum paham dengan penjumlahan pecahan dengan menggunakan KPK atau dengan pecahan senilai.sementara siswa yang belum paham dengan KPK akan ditindak lanjuti dengan remedial juga terutama tentang penjumlahan dengan menggunakan pecahan senilai.

Pengamatan teman sebaya tentang pengelolaan kelas menjadi acuan juga untuk memperbaiki proses pembelajaran,antara lain siswa yang masih kurang aktif didalam kelompok akan dipantau oleh guru agar mau bertanya pada siswa yang mampu memahami tentang materi pembelajaran yang belum dipahami,guru juga mendorong siswa untuk membantu teman yang kurang untuk dapat memahami materi sajian,dengan kata lain guru memamfatkan teman sebagai guru sebaya.Penulis juga menyarankan kepada teman-teman agar penanaman konsep perkalian, penjumlah,pembagian dan pengenalan pecahan ,baik pecahan senilai maupun pecahan berpenyebut tidak sama dimulai dari kelas rendah sehingga ketika sudah duduk dikelas yang lebih tinggi ,pemahaman tentang penjumlahan, perkalian maupun konsep pecahan sudah dipahami siswa sehingga ketika siswa sudah menduduki kelas yang lebih tinggi siswa sudah tertanam konsep dasar tentang matri sajian yang disajikan guru.

\section{Kesimpulan}

Berdasarkan hasil penelitian yang telah dipaparkan di depan, penulis menarik kesimpulan bahwa model pembelajaran kooperatif tipe STAD mata pelajaran metematika pada materi penjumlahan dan pengurangan pecahan dapat meningkatkan hasil belajar siswa. Kesimpulan ini yaitu pada awal siklus atau sebelum dilakukan pembelajaran matematika dengan model pembelajaran kooperatif tipe STAD, skor rata-rata hasil belajar siswa adalah 65,00. Sementara skor ideal yang mungkin dicapai siswa adalah 100,00. Pada siklus I atau setelah dilakukan pembelajaran matematika dengan model pembelajaran kooperatif tipe STAD, skor ratarata hasil belajar siswa pada pokok bahasan penjumlahan dan pengurangan pecahan biasa yang berpenyebut sama dan yang berpenyebut berbeda adalah 69,375 dari skor ideal yang mungkin dicapai 100,00. Pada siklus II atau setelah dilakukan pembelajaran matematika dengan model pembelajaran kooperatif tipe STAD, skor rata-rata hasil belajar siswa pada pokok bahasan penjumlahan pecahan campuran berpenyebut sama dan beda adalah 73,75 dari skor ideal yang mungkin dicapai 100,00. 


\section{DAFTAR PUSTAKA}

Departemen Pendidikan Nasional, 2003, Kurikulum 2004. (http: // puskur. Net/ inc/ SD/ Matematika. Pdf. Diakses 1 Desember 2009).

Eggen dan Kauchak. Pengertian Pembelajaran, Online: 6 Agustus 2007, http//Eggan dan Kauchak. Blog. Persimpangan. Woordpres. Com. Diakses 29 Juli 2009.

Hamalik. O, Proses Belajar Mengajar, Jakarta: PT Bumi Aksara, 2007.

Kasboelah, K. Penelitian Tindakan Kelas (PTK), Departemen Pendidikan dan Kebudayaan, Dirjen Pendidikan Tinggi, 1998.

Mustaqin. Psikologi Pendidikan, Yogyakarta: Depdiknas, 2004.

Ratumanan, Tenwey Gerson, Belajar dan Pembelajaran, IKAPI: UNESA University Press, 2002.

Sudijono, Anas. Pengantar Statistika Pendidikan, Jakarta: Rajawali Press, 1995.

Anita, Lie. 2005. Cooperative Learning. Cetakan ke III. Jakarta: Grasindo

BSNP, 2004, Pedoman Penilaian Evaluasi Hasil Belajar di SD. Jakarta. Depdiknas

Johar, Rahmah dkk. 2006. Startegi Belajar Mengajar. Banda Aceh : FKIP Universitas Syiah Kuala.

Hartoyo. 2000. Strategi Belajar Mengajar Matematika. Malang: IKIP Malang.

KBBI. 1996. Edisi Kedua. Jakarta: Balai Pustaka.

Maidiyah. 2004. Pembelajaran kooperatife. Jakarta Rineksa Cipta.

Nur, Muhammad. 1996.2005 Pembelajaran Kooperatif. Surabaya. Universitas Negeri Surabaya.

Sanjaya, Wina. 2007. Strategi Pembelajaran Berorientasi Standar Proses Pendidikan Jakarta: Kencana

Soetomo. 1993. Dasar-dasar Interaksi Belajar Mengajar. Surabaya Usaha Nasional.

Jakarta: Balai Pustaka.2005. Metodelogi Penelitian. Jakarta: Balai Pustaka Slameto.2003. Belajar dan Faktor-faktor yang Mempengaruhinya. Jakarta: Rineka Cipta. 